\title{
PROBLEMATIKA NOMOS DAN HUBUNGANNYA DENGAN KASIH KARUNIA DALAM SURAT ROMA
}

\author{
Prabowo \\ Sekolah Tinggi Teologi Injili Indonesia - Bali \\ E-mail:angel_dorothea@yahoo.co.id
}

\begin{abstract}
It's long time, churches debate on the application of the law to believers today. Some of the figures found grace is no longer relevant in the church. But some Christian leaders argue otherwise, saying that the law is still relevant and should be done. But, now a days many interpretations that are not right about Paul's theology on the application of the law in a period of grace. False interpretations of verses taken from Paul's letters caused God's people to be confused. Therefore, there is a need for proper interpretation through the process of exegesis of the Book of Romans 2-8, resulting in the existence of the correct interpretation of the law in a period of grace.

From the background and the problems, this research focused to sharpen understanding of the problems related to the application of grace in the church today. Researchers used descriptive method to describe it. Then the authors conducted a study exegesis consisting of an observational analysis, textual analysis, structural analysis, grammatical analysis, lexical analysis, historical analysis or conceptual, analytical theological and exegetical analysis of Romans 2-8.

The purpose of this study is the first, to understand the interrelationships of the law and grace; second, to understand the uniqueness of Paul's theology in describing the application of the law in a period of grace; Third, investigate exegesis mean passages from Paul's Letter to the Romans chapters 2-8 which discusses the relevance of the law and grace.

The results of the discussion found several things: First, the assumption that Paul abolishes the law is not correct. Paul did not abolish the Law in a period of grace. Second, the law still relevant in the church today. Jesus fulfill the law for believers, so that believers can do the latter by the power of the Holy Spirit. And keep in mind that God has put His laws are no longer in tablets of stone dead, but in the mind of his people. Third, the law has a unique role and functions in the day of grace. The Law was God's will for believers because it still remains a self-revelation of God.

Recommended for ministers, pastors, and teachers of theology seriously investigate the truth about the existence of the law in the church today, so that people are not confused by every falseteaching.
\end{abstract}

Keywords: The Law, Grace, Paul's Theology 


\section{Abstrak}

Sudah lama sekali, gereja berdebat tentang penerapan hukum kepada orang percaya hari ini. Beberapa tokoh menemukan kasih karunia tidak lagi relevan di gereja. Tetapi beberapa pemimpin Kristen berpendapat sebaliknya, dengan mengatakan bahwa hukum masih relevan dan harus dilakukan. Namun, sekarang ini banyak tafsir yang tidak benar tentang teologi Paulus tentang penerapan hukum dalam masa kasih karunia. Penafsiran yang salah dari ayat-ayat yang diambil dari surat-surat Paulus menyebabkan umat Tuhan menjadi bingung. Oleh karena itu, diperlukan penafsiran yang tepat melalui proses penafsiran Kitab Roma 2-8, sehingga terjadi penafsiran hukum yang benar dalam masa rahmat.Dari latar belakang dan permasalahan tersebut, penelitian ini difokuskan untuk mempertajam pemahaman tentang permasalahan terkait penerapan anugerah di gereja saat ini. Peneliti menggunakan metode deskriptif untuk mendeskripsikannya. Kemudian penulis melakukan studi tafsir yang terdiri dari analisis observasional, analisis tekstual, analisis struktural, analisis gramatikal, analisis leksikal, analisis historis atau konseptual, analisis teologis dan analisis eksegetik Roma 2-8.

Tujuan dari studi ini adalah yang pertama, untuk memahami keterkaitan antara hukum dan rahmat; kedua, memahami keunikan teologi Paulus dalam menjelaskan penerapan hukum dalam masa kasih karunia; Ketiga, menyelidiki eksegesis yang berarti bagian-bagian dari Surat Paulus kepada Roma pasal 2-8 yang membahas relevansi hukum dan kasih karunia.Hasil diskusi menemukan beberapa hal: Pertama, anggapan bahwa Paulus menghapus hukum adalah tidak tepat. Paulus tidak menghapus Hukum dalam masa kasih karunia. Kedua, hukum masih relevan di gereja saat ini. Yesus menggenapi hukum untuk orang percaya, sehingga orang percaya dapat melakukan yang terakhir dengan kuasa Roh Kudus. Dan perlu diingat bahwa Tuhan telah meletakkan hukum-hukum-Nya tidak lagi di loh batu mati, tetapi di benak umat-Nya. Ketiga, hukum memiliki peran dan fungsi yang unik di hari kasih karunia. Hukum adalah kehendak Tuhan bagi orang percaya karena itu tetap merupakan wahyu Tuhan.

Dianjurkan agar pendeta, pendeta, dan guru teologi menyelidiki dengan serius kebenaran tentang keberadaan hukum di gereja saat ini, agar masyarakat tidak dibingungkan oleh setiap kesalahan pengajaran.

Kata Kunci: Hukum, Rahmat, Teologi Paulus

\section{PENDAHULUAN}

Pandangan Paulus tentang nomos atau hukum tidak diragukan lagi merupakan salah satu tantangan hermeneutikal yang paling kompleks yang ditemukan dalam semua tulisannya. Tidak sedikit karya tulis dan artikel mengenai teologi Paulus tentang hukum Taurat secara mengherankan terus muncul di sepanjang zaman.

Barangkali, sepantasnyalah demikian mengingat kompleksitas dan sulitnya isuisu yang terlibat di dalamnya. Salah satu contohnya, apakah Paulus berargumentasi tentang penghapusan hukum Musa ataukah validitas hukum tersebut tetap berkesinambungan namun berada di bawah 
pelaksanaan ikatan perjanjian yang baru? Dalam pengertian apa dan sampai sejauh mana hukum Taurat tetap berlaku, dan sebaliknya, dalam pengertian apa serta sejauh mana hukum itu tidak lagi valid? Jika hukum itu tidak lagi berlaku, apakah kegunaannya bagi orang percaya zaman Perjanjian Baru, mengingat bahwa hukum tersebut adalah bagian dari firman yang diinspirasikan? Ini hanya beberapa contoh pertanyaan yang dihadapi oleh mereka yang mempelajari teologi biblika dan sistematika.

Para Reformator seperti Luther dan Calvin, sependapat bahwa tidak seorang pun bisa dibenarkan oleh perbuatan hukum Taurat, karena tidak seorang pun dapat dengan sempurna memelihara tuntutantuntutan hukum tersebut. Hanya ketaatan yang sempurna yang membenarkan dan karena semua manusia adalah orang berdosa, pembenaran tidak dapat diperoleh melalui ketaatan pada hukum Taurat. Segala bentuk legalisme atau keyakinan di mana seseorang bisa memperoleh hadiah tanda jasa dari Allah karena telah melakukan perbuatan-perbuatan baik, sehingga orang tersebut kemudian memperoleh kehidupan kekal, bersumber dari penyembahan diri sendiri.

Injil yang benar mengajarkan bahwa semua manusia secara fundamental dicemari dosa, dan karena itu keselamatan hanya tersedia dengan percaya kepada Allah, yang telah mengutus Yesus Kristus untuk mendamaikan. Tanpa anugerah Allah yang tersedia dalam Kristus, umat manusia akan terhilang selamanya tanpa pengharapan karena tidak ada kuantitas usaha manusia atau tindakan yang bisa memberikan keselamatan. Keselamatan hanya datang dari iman dan hanya anugerah atau kasih karunia semata.

Berkaitan dengan anugerah atau kasih karunia, yang menarik, hal itu adalah satu-satunya keunikan kepercayaan Kristen dibandingkan dengan keyakinan lain. Hal ini dikatakan oleh C.S. Lewis, seperti yang dilansir oleh Philip Yancey dalam bukunya Keajaiban Kasih Karunia:

Dalam konferensi di Inggris tentang perbandingan agama, para ahli dari seluruh dunia memperdebatkan kepercayaan manakah, jika ada, yang membuat iman Kristen menjadi unik. Mereka mulai menelusuri berbagai kemungkinan. Inkarnasi? Agama lain memiliki berbagai versi dewa-dewa lain juga memiliki penuturan tentang kembalinya orang mati. Debat itu berlanjut cukup lama, sampai C.S. Lewis masuk ke ruangan itu. "Ribut-ribut soal apa ini?" tanyanya, dan dijawab bahwa rekan-rekannya sedang membicarakan sumbangan unik Kekristenan di tengah agama-agama lain di dunia. Lewis menjawab, "Oh, itu mudah. Kasih 
Jurnal Teologi \& Pelayanan ( Kerusso )

E-ISSN: 2714-9587

P-ISSN: 2407-554X

karunia."1

Kasih karunia merupakan pemberian

Tuhan kepada manusia tanpa ada unsur kelayakan pada penerimanya. Berkaitan dengan arti kasih karunia, Chris Marantika, memberikan definisi yang lebih komprehensif, yang diambil dari penggunaan kata kharis dalam Perjanjian Baru.

Penggunaan kharis dalam PB dapat disimpulkan sebagai berikut: (1) Konsep anugerah dalam PB meliputi juga arti dalam bahasa Ibrani dan Yunani klasik; Pemberian cuma-cuma anugerah Allah dalam pribadi Kristus itu adalah arti khusus PB. Pengorbanan diri-Nya sendiri sebagai anugerah (Rm. 6:10; Rm. 5:15; Ef. 2:8) dan yang menang atas hukuman dan kuasa dosa (Rm. 5:12; 6:1-23); (3) Bila telah diterima, anugerah itu memerintah hidup rohani penerima dan mendatangkan anugerah demi anugerah. Sehingga anugerah Allah melengkapi, menguatkan dan mengontrol semua bidang hidupnya (Kol. 4:6; 1Tes. 2:16-17; 2Tim. 2:1); dan (4) Akibatnya orang-orang beriman (Kristen) itu memulangkan syukur kepada Allah bagi kekayaan anugerah yang tak terlukiskan itu (2Kor. 9:15). Jadi dalam anugerah Allah ada

\footnotetext{
${ }^{1}$ Philip Yancey,KeajaibanKasihKarunia (Interaksara: 1999), 49.

${ }^{2}$ Chris Marantika, Doktrin Keselamatandan

Kehidupan Rohani, (Iman Press, 2002), 37-38.
}

penebusan, pimpinan, penghiburan, dan pengharapan abadi. ${ }^{2}$

Hal yang senada diungkapan oleh Michael L. Brown, yang menuliskan tentang kasih karunia sebagai berikut: Kasih karunia (GRACE) itu bukan hanya kemurahan Tuhan yang tidak layak kita terima, walaupun itu adalah titik awal yang bagus, sering diekspresikan sebagai God's Riches At Christ's Expense (Kekayaan Tuhan dengan Pengorbanan Kristus). Kasih karunia juga adalah kuasa-Nya yang terus memberdayakan, pekerjaan-Nya yang terus berlanjut di dalam kita - apa yang Yesus lakukan bagi kita ketika Ia menyelamatkan kita sebagai orang berdosa yang tersesat dan apa yang terus Ia kerjakan di dalam, melalui, dan untuk kita sekarang setelah kita diselamatkan. Mengutip perkataan A.M. Hunter, "Kasih karunia adalah kasih Tuhan yang mengampuni dan cuma-cuma di dalam Kristus untuk orang berdosa dan bekerjanya kasih itu di dalam hidup orang Kristen."3

Membahas tentang kasih kasih karunia atau anugerah tidaklah mudah. Hal ini seperti yang dituliskan oleh Philip Yancey dalam bukunya Keajaiban Kasih

\footnotetext{
${ }^{3}$ Michael L. Brown, Hyper Grace, Kasih KaruniaOverdosis: Menyingkap Bahaya Kasih Karunia Modern, (Nafiri Gabriel, 2015), i-ii.
} 
Karunia:

Kasih karunia bukanlah subyek yang mudah bagi seorang penulis. Meminjam komentar E.B. White tentang kasih karunia, "[Kasih karunia] bisa dibedah, seperti katak, tapi ia akan mati dalam prosesnya, dan isi perutnya tidak menarik bagi siapa pun kecuali bagi pikiran yang murni ilmiah." ${ }^{4}$

\section{Kasih karunia datang melalui} kedatangan Tuhan Yesus ke dalam dunia. Yohanes menekankan bahwa "hukum Taurat diberikan oleh Musa; tetapi kasih karunia dan kebenaran datang oleh Yesus Kristus" (Yoh. 1:16). Tuhan Yesus sendiri mengatakan, "Janganlah kamu menyangka, bahwa Aku datang untuk meniadakan hukum Taurat atau kitab para nabi. Aku datang bukan untuk meniadakannya, melainkan untuk menggenapinya. Karena Aku berkata kepadamu: Sesungguhnya selama belum lenyap langit dan bumi ini, satu iota atau satu titikpun tidak akan ditiadakan dari hukum Taurat, sebelum semuanya terjadi” (Mat. 5:17-18). Dari ayat-ayat tersebut memang nampak bahwa adanya titik persinggungan antara hukum Taurat dan kasih karunia.

$$
\text { Gereja-gereja telah lama }
$$
memperdebatkan tentang penerapan hukum Taurat di masa kini. Beberapa tokoh

\footnotetext{
${ }^{4}$ Philip Yancey, KeajaibanKasihKarunia, (Penerbit Interaksara, 1999), 17.
}

berpendapat bahwa kasih karunia sudah tidak relevan lagi bagi orang percaya masa kini. Tetapi beberapa tokoh berpendapat sebaliknya dengan mengatakan bahwa hukum Taurat masih relevan dan harus dilakukan gereja masa kini.

\section{METODE PENELITIAN}

Metode yang dipakai dalam penelitian ini menggunakan studi tinjauan pustaka dengan mengumpulkan buku-buku yang sudah di tetapkan untuk referensi dalam penelitian ini.

\section{HASIL DAN PEMBAHASAN}

Paulus memulai dengan pengertian tradisional di mana hukum adalah hukum PL, meskipun penggunaannya tidak seragam. Dekalog adalah inti dari hukum ( $\mathrm{Rm}$ 13:8), tapi nomos terdiri hukum lainnya dan dapat digunakan untuk hukum tunggal (Rm. 7:2). Hukum menuntut tindakan; salah satunya dengan melakukannya ( $\mathrm{Rm}$ 2:25). Ini merupakan tinggal di dalam Allah. Bahkan mereka yang tidak tahu hukum, tetapi melakukannya, adalah 'menjadi hukum untuk diri mereka sendiri (bukan hukum yang mereka pilih sendiri) ( $\mathrm{Rm} 2: 12$ ).

Hukum adalah salah satu kehendak mengungkapkan dari satu Allah. Hal 
demikian dapat dipersonifikasikan ( $\mathrm{Rm}$. 3:19; 7:1). Dalam kesempatan tersebut nomos mungkin adalah Pentateukh (Rm 03:21; Gal 4: 21). Sebuah penggunaan kiasan juga dapat dilihat, seperti ketika Paulus mengacu pada hukum iman (Rm 3: 27). Hukum (Rm. 7:21) adalah mungkin diambil dengan cara ini, yaitu, aturan bahwa ketika kita ingin melakukan yang benar, yang jahat itu justru yang dilakukan. Contoh lain adalah hukum dosa (Rm. 7:25), hukum semangat hidup (8: 2), dan hukum Kristus (Gal. 6:2).Memahami Materi Hukum menurut Paulus. Salib mendominasi pemahaman materi Paulus. Hal ini menjelaskan meniadakan dan penegasan hukum tak bisa dijelaskan.

Hukum adalah kehendak Allah yang baik, sehingga menentang itu menentang Tuhan ( $\mathrm{Rm}$ 8:7). Hal ini berorientasi pada tindakan manusia, bukan hanya pengetahuan ( $\mathrm{Rm}$ 2:.17). Untuk melakukannya adalah untuk memiliki kehidupan berdasarkan prestasi, tapi ini menimbulkan menyombongkan diri, dan pada kenyataannya hukum tidak dapat memberikan kehidupan (Gal. 3:21), karena tidak ada yang benar-benar membuat itu. Hukum harus ditegaskan karena identik dengan kebaikan. Jika perbedaan dibuat antara orang Yahudi yang memilikinya dan bangsa-bangsa lain yang tidak, yang bangsa-bangsa lain divonis dan semua jatuh di bawah putusannya (Rm 1;2). Oleh karena itu, semua disebut iman di dalam Kristus untuk keselamatan (Gal. 3:28).

Dalam kaitannya dengan dosa manusia, hukum pertama melarang itu ( $\mathrm{Rm}$. 7:7, dll), kemudian membuka kedok sebagai pemberontakan terhadap Allah (Rm. 7:9), kemudian mengutuk itu (5:13), sehingga akan ada banding lebih lanjut untuk hukum itu, dengan demikian kita untuk melakukan itu dengan otoritas ilahi (Gal. 3:22), mengesampingkan semua upaya pembenaran diri, dan akhirnya membawa kita mati (Rm. 7:9-10). Ini adalah kelemahan hukum, yang menyebabkan Paulus merasa dari urutan ini (Gal. 4:3), tidak dapat terlepas, tetapi justru karena kekudusan sebagai wahyu kehendak ilahi. Peniadaan ini terletak pada penegasan dari tindakan mengampuni Allah di dalam Kristus (Rm 3: 21; 8: 1; Flp 3:9). Luar iman di dalam Kristus, orang masih di bawah hukum (Kol 2: 20), tetapi dengan kematian dan partisipasi Kristus di dalamnya terdapat terjemahan dari bidang hukum (Rm. 10:4) ke dalam hubungan keputraan. Kristus, maka, menggantikan hukum sebagai jalan keselamatan; bagi mereka yang masih mencari kebenaran oleh hukum, Kristus telah mati. Namun salib menerima putusan hukum (Gal. 2:19; 3: 13). Hal ini memenuhi hukuman (2Kor 5:21; Rm 5: 6). Ini adalah pemenuhan hukum dalam ketaatan 
sempurna (Flp. 2:5) dan cinta (Rm 8:34). Iman tersirat mengecam dalam hukum, dan dengan itu datanglah ketaatan baru dimana hukum datang ke pemenuhan dalam buah Roh (Gal. 5: 22-23). Ini adalah hukum Kristus (Gal. 6:2) di mana maksud sebenarnya dari hukum tersebut direalisasikan, sehingga Paulus dapat mengatakan bahwa Injil menetapkan daripada menghapuskan hukum itu (Rm. 3:31). Di tanah ini Paulus sendiri secara bebas dapat menjaga ketentuan konkret hukum Musa dalam melayani orang-orang Yahudi (1Kor 9:20), dan ia dapat menyarankan orang-orang Yahudi untuk tidak meninggalkan sunat mereka (1Kor 7:18). Memang, hukum adalah tempat di mana Paul mencari bimbingan dalam kehidupan masyarakat, bukan sebagai argumen yang menentukan, tetapi dalam konfirmasi apa yang dikenal dalam ketaatan iman.

Pandangan Paulus tampaknya berasal tidak begitu banyak dari pengalaman hukum pribadi sebagai aplikasi yang konsisten dengan hukum iman kepada Tuhan yang disalibkan dan bangkit, meskipun mungkin diperdebatkan apakah ia bekerja keluar dari pandangannya secara sendiri atau dalam perdebatan dengan jawaban yang diusulkan oleh orang lain di sekelilingnya. Tentu ia melihat dari awal antitesis antara cara hukum dan cara iman.

\section{Fungsi Hukum Taurat}

1. Taurat membawa pengenalan akan dosa (Rm 3:20; 4:15; 7:7).

2. Taurat merangsang dosa - Taurat ditambahkan supaya pelanggaran menjadi semakin banyak (Rm 5:20)

3. Taurat itu bersifat rohani, yaitu untuk mencapai hasil-hasil rohani

4. Taurat itu memberatkan (Gal 5:3; Gal $3: 10)$

5. Taurat menjatuhkan kutuk (Gal 3:13)

6. Melalui perbuatan-perbuatan melakukan Taurat orang tidak dapat memperoleh kebenaran

7. Taurat adalah penuntun sampai Kristus datang (Gal 3:24)

8. Taurat berakhir di dalam Kristus ( $\mathrm{Rm}$ $10: 4)$

\section{Nomos adalah Hukum Tuhan yang Kudus, Baik dan Benar}

Hukum Taurat bukanlah sesuatu yang jahat dan harus dihindari, tetapi justru hukum Taurat itu kudus dan baik. Hal ini seperti yang tertulis di Roma 7:12 "Jadi hukum Taurat adalah kudus, dan perintah itu juga adalah kudus, benar dan baik." Hukum Taurat diberikan oleh Tuhan sendiri. Tidak mungkin Tuhan memberikan seseuatu yang bertentangan dengan sifatNya sendiri. Tetapi memang ada pergumuluan di sini, kalau memang Taurat itu tidak menguntungkan bagi orang Yahudi mengapa Allah yang baik memberikan kepada mereka? Gerald F. Hawthorne, dalam bukunya yang berjudul Dictionary of Paul and his Letters, mengatakan:

Paul points out carefully that the Law and 
sin are identical (Rom. 7:7). To the contrary, the Law is holy, righteous, good and spiritual (Rom. 7:12, 14; cf. 7:22); it is only so closly allied with sin because it shows sin for the evil transgression that it is and condemns the transgressor. It accomplishes this, according to Paul, in three ways. First, it brings knowledge of sin by making God's will explicit so that people can know God's will and understand that they have not done it (Rom. 3:20; 4:15; 5:13; 7:7, 21-23). Second, the Law demonstrates how insidious $\sin$ is by suggesting to fallen humanity ways in which it can rebel against God (Rom 7:7-12; cf. 5:20). Finally, "the Law brings wrath" (Rom 4:15; cf. 1:18), for it contains a list of dire consequences which God ordains for those who disobey its commands. Not surprisingly, then, believers are "no longer under," have "died to" and have "died to" and have been "freed from" this "Law of sin and death" (Rom 6:14; 7:4; $7: 6 ; 8: 2)^{5}$

\section{Nomos adalah Alat Penghakiman Tuhan}

Hukum Taurat menyadarkan seseorang akan dosanya, tetapi tidak dapat menyelesaikan dosa orang tersebut. Walaupun bagi Paulus Taurat tetap merupakan pengungkapan yang benar dan kudus tentang kehendak Allah. Mustahil bagi manusia untuk dibenarkan dengan

${ }^{5}$ Gerald F. Hawthorne (Editors), Dictionary of Paul and his Letters (Inter Varsity Press, Leicester, melakukan hukum Taurat. Sebenarnya tak ada satu hukumpun yang dapat menjadikan manusia benar dengan Allah.

Alasan yang paling mendasar adalah menyangkut kelemahan dan keberdosaan manusia yang menjadikannya tak berdaya menaati tuntutan Taurat. Kondisi hati manusia itu tak dapat ditolong oleh hukum apa pun. Kelemahan daging (Rm. 8:3) dan sifat manusia yang berdosa (Rm. 7:23) tak dapat diubah oleh Taurat. Ide dari sebagian rabi bahwa dorongan-dorongan yang jahat dari manusia dapat diatasi dengan mempelajari Taurat, ditolak sama sekali oleh Paulus.

Alasan mengapa Taurat tidak dapat membenarkan manusia yang berdosa adalah karena Taurat adalah hukum lahiriah, sedangkan hati manusia yang berdosa membutuhkan kuasa batin untuk mengubahnya. Taurat adalah hukum tertulis dan bukan kehidupan yang diberikan oleh Roh Allah (Rm. 7:6). Ide ini diperluas dalam uraian tentang perbedaan antara perjanjian yang baru dan perjanjian yang lama. Perjanjian Taurat yang lama terdiri dari perintah-perintah yang ditulis pada loh batu, yang hanya dapat menyatakan kehendak Allah, namun hukum yang tertulis itu menghakimi manusia sebagai orang berdosa dan menempatkan mereka di bawah

England, 1993), 54. 
Jurnal Teologi \& Pelayanan ( Kerusso )

E-ISSN: 2714-9587

P-ISSN: 2407-554X

hukuman kematian.

Taurat itu ditambahkan bukan untuk menyelamatkan manusia dari dosa mereka, melainkan untuk menunjukkan kepada mereka apa sebenarnya dosa itu (Rm. 3:20; 5:13, 20). Dengan menyatakan kehendak Allah, dan menunjukkan apa yang dilarang Allah, maka Taurat menunjukkan apa dosa sebenarnya. Dengan melarang iri hati menunjukkan bahwa iri hati adalah dosa (Rm. 7:7). Jadi kuasa dosa adalah Taurat, karena hanya melalui Tauratlah dosa itu didefinisikan secara jelas. Taurat yang menyatakan bahwa Taurat menyebabkan dosa menjadi semakin banyak (Rm. 5:20) tidak berarti bahwa Taurat itulah sebenarnya yang menimbulkan dosa dan menjadikan manusia lebih berdosa daripada ketika dia hidup tanpa Taurat. Taurat sendiri bukanlah dosa atau pun menghasilkan dosa (Rm. 7:7). Sebaliknya Taurat itu membeberkan situasi manusia yang sebenarnya agar pertanggungjawabannya kepada Allah sebagai orang berdosa dapat dinyatakan (Rm. 3:19).

Jadi Taurat adalah alat penghukuman (Rm. 5:13), murka (Rm. 4:15), dan kematian (Rm. 7:19). Bukan Taurat itu sendiri yang menghasilkan situasi yang mengerikan itu, melainkan dosa di dalam diri manusia itulah yang menjadikan Taurat sebagai alat kematian (Rm. 7:13). Perhatian Paulus dalam bagian ini bukanlah kehidupan manusia di dalam daging melainkan sifat Taurat itu. "Apakah hukum Taurat itu dosa?" (Rm. 7:7). Tidak, tetapi karena dosa diam di dalam manusia, maka Taurat yang kudus menunjukkan keadaan dosa yang sesungguhnya, sehingga dengan demikian menjadi alat kematian. Namun dosa itulah yang membawa maut, bukannya Taurat (Rm. 7:10-11). Dengan demikian Taurat menjadi sarana penghakiman, bukan sarana pembenaran seperti yang disangka oleh orang-orang Yahudi.

Baik orang Yahudi maupun orang kafir sama tidak ada bedanya, karena hati nurani orang kafir menjadi Taurat bagi mereka. Mereka semua telah tertuduh dan berada di bawah kuasa dosa, dan tinggal menanti hari penghakiman dinyatakan. Tidak ada yang mengerti dan mencari Allah. Sebaliknya, semua orang telah "menyeleweng" dan "tidak berguna." Kata 'telah menyeleweng' berarti menyimpang dari kebenaran Allah dan telah memakai kebenarannya sendiri. Kata 'semua tidak berguna' artinya semua telah rusak total luar dalam. Kata 'tidak ada yang berbuat baik' menunjukkan semua orang tanpa terkecuali tidak ada yang layak di hadapan Allah.

Dalam Roma 3:13-17 telah dijelaskan bahwa semua orang tanpa terkecuali telah tercengkram oleh dosa sehingga tidak berdaya kecuali menyerah kepada dosa dengan segala cara dan memakai segala 
sarana yang ada, yaitu mulut (ay. 14) dan kaki (ay. 15); perkataan dan perbuatan. Jadi akar dari segala macam dosa, baik itu dosa perkataan atau pun perbuatan adalah tidak adanya rasa takut akan Allah.

Tidak ada seorang pun yang dapat dibenarkan oleh 'perbuatan-perbuatan hukum Taurat' ia sedang mengacu pada hukum itu secara keseluruhan, dengan menekankan bahwa tidak ada seorang pun yang dapat dibenarkan dengan Allah melalui karya atau ketaatan kepada hukum tersebut. Namun, meski hukum Taurat tidak memiliki peran dalam pembenaran, namun ia berfungsi untuk menyadarkan seseorang akan dosanya ketika ia jatuh dan mengarahkan orang tersebut pada keselamatan yang Allah sediakan di dalam Yesus Kristus. Karena itu, usaha apa pun untuk memperoleh keselamatan dengan cara menaati hukum Taurat berarti mengkompromikan anugerah dan membawa pada legalisme karena dalam lingkup pembenaran tidak ada tempat bagi usaha manusia dan hukum Taurat.

Dalam Roma 3:19-20 telah dibahas bahwa karena semua orang berbuat dosa, maka semua orang harus bertanggung jawab atas akibatnya. Dikatakan, "Tetapi kita tahu, bahwa segala sesuatu yang tercantum dalam Kitab Taurat ditujukan kepada mereka yang hidup di bawah hukum Taurat, supaya tersumbat setiap mulut dan seluruh dunia jatuh ke bawah hukuman Allah. Sebab tidak seorangpun yang dapat dibenarkan di hadapan Allah oleh karena melakukan hukum Taurat, karena justru oleh hukum Taurat orang mengenal dosa." Dengan dipakainya pernyataan 'tetapi kita tahu' dalam kaitannya dengan hukum Taurat, berarti Paulus sedang menegaskan bahwa apa yang tercantum dalam kitab Taurat itu ditujukan bagi bangsa Yahudi. Dengan kata lain, kitab suci mereka sendiri telah menyatakan bahwa mereka bersalah, sehingga mereka tidak dapat berkilah. Jika orang Yahudi telah divonis atau ditetapkan bersalah oleh kitab sucinya sendiri, apalagi orang-orang kafir, maka setiap mulut tersumbat artinya bungkan, tidak ada seorang pun yang bisa memberi alasan atau membuat pembelaan. Dengan demikian, semua orang "seluruh dunia" tanpa terkecuali, jatuh bersimpuh di bawah penghakiman Tuhan. Dari sini orang Yahudi sadar bahwa ternyata Taurat bukan menjadi sumber pembenaran melainkan sebagai sarana pengenalan akan dosa. Melalui hukum Taurat, orang akan mengenali dirinya sebagai orang berdosa bukan sebagai orang benar.

Hukum Taurat diberikan tidak pernah dimaksudkan untuk pembenaran melainkan untuk menyatakan kesalahan dan standar penghakiman. Kesalaham orang Yahudi adalah memakai hukum taurat untuk 
Jurnal Teologi \& Pelayanan ( Kerusso )

E-ISSN: 2714-9587

P-ISSN: 2407-554X

mengejar pembenaran dengan tujuan bebas dari penghakiman. Tidak ada satu orang pun yang bisa dibenarkan oleh perbuatannya, karena hukum Taurat tidak membuahkan pembenaran melainkan pelanggaran; tidak menghasilkan pengetahuan akan Allah melainkan pengetahuan akan dosa. Taurat tidak pernah menyatakan seseorang benar, melainkan menyatakan seseorang itu berdosa.

Dalam Roma 3:21 pembenaran Allah dijelaskan, "Tetapi sekarang, tanpa hukum Taurat kebenaran Allah telah dinyatakan, seperti yang disaksikan dalam Kitab Taurat dan Kitab-kitab para nabi.” Istilah 'sekarang' penting untuk dicermati. Karena kata tersebut, tidak menunjuk pada waktu yang panjang sebelum dan sesudah Taurat, melainkan temporal, yaitu menunjuk 'sebelum bergantung kepada dan sesudah bergantung kepada' dalam kaitannya dengan konteks ini, jelas yang dimaksudkan adalah sebelum percaya kepada Tuhan yesus dengan setelah percaya kepada Tuhan Yesus. Yang hendak ditegaskan di sini adalah jenis pembenaran yang dipertontonkan dan ditawarkan oleh Allah adalah melalui iman bukan melalui Taurat. Jika Taurat bukan saran pembenaran, melainkan sarana penghakiman, lalu dengan sarana apa kebenaran diperoleh? Jawabannya ada dalam ayat 22-23, "yaitu kebenaran Allah karena iman dalam Yesus
Kristus bagi semua orang yang percaya. Sebab tidak ada perbedaan. Karena semua orang telah berbuat dosa dan telah kehilangan kemuliaan Allah."

Jelas sekali yakni kebenaran melalui iman, bukan melalui suatu usaha. Dasar pembenaran melalui iman bagi orang berdosa adalah kasih karunia Allah. Pembenaran Allah bagi mereka yang percaya ditentukan dua kata, yaitu 'kasih karunia' dan 'cuma-Cuma'. Kasih karunia sebagai dasarnya dan cuma-cuma sebagai akibatnya. Cara pembenaran itu diwujudkan melalui penebusan. Kata 'penebusan' dari kata Apolutrosis yang berasal dari kata kerja lutroo yang penggunaannya adalah untuk membebaskan budak dari kekuasaan majikan melalui pembayaran yang setimpal. Dengan kaitannya dengan pembenaran, manusia dibenarkan melalui iman karena Kristus telah membayar mereka dari tuntutann dosa dan melalui pembayaran itu secara otomatis mereka telah dibebaskan dari kuasa dosa. Sasaran penebusan adalah pemberesan atau penyelesaian dosa. Tujuannya supaya setiap orang yang percaya dimerdekakan atau dibenarkan sehingga menjadi orang bebas tanpa tuduhan.

Selain Kristus ditentukan sebagai sarana penebusan yang setimpal, Ia pun juga ditentukan sebagai sarana pendamaian (ayat 25). Pendamaian adalah akibat wajar 
dari penebusan. Dosa telah menyebabkan hubungan antara manusia dengan Allah terputus. Hasil lain dari penebusan adalah Allah dipahami sebagai Allah yang maha adil karena tidak membiarkan dosa dan membenarkan dosa begitu saja, melainkan dengan membayar lunas tuntutan dosa melalui karya penebusan Kristus. Jadi karya penebusan Kristus adalah untuk menunjukkan keadilan Allah yang telah berabad-abad membiarkan dosa berkuasa atas manusia (ayat 26).

Efek samping dari pembenaran Allah melalui iman kepada baik orang Yahudi maupun orang Yunani adalah menghapuskan kesombongan dan perbedaan antara mereka, dan juga sekaligus meneguhkan hukum Taurat (ayat 27-31). Dalam ayat 31 dinyatakan bahwa pembenaran melalui iman tidak menghapus fungsi hukum Taurat. Karena memang Taurat tidak berfungsi sebagai sarana pembenaran melainkan sarana penghakiman. Pembenaran melalui iman membuktikan bahwa manusia berdosa dan hukum Taurat adalah suci, Taurat itu benar dan semua manusia bersalah. Pembenaran melalui iman membuktikan bahwa Taurat itu diperlukan sebab tanpa Taurat manusia tidak sadar akan perlunya pembenaran melalui iman. Pembenaran melalui iman kepada Kristus sebagai penggenap Taurat bukan pembatal Taurat.

\section{KESIMPULAN}

Pertama, anggapan bahwa Paulus membatalkan hukum Taurat adalah tidak benar. Paulus tidak meniadakan Taurat di masa anugerah. Dalam Roma 2-8 membahas bahwa masa hukum Taurat telah berakhir seiring kedatangan Tuhan Yesus ke dunia untuk menggenapi tuntutan hukum Taurat di dalam diri-Nya melalui kematianNya di atas kayu salib. Namun tidak berarti hukum Taurat dibatalkan. Hukum Taurat bukanlah sesuatu yang jahat dan harus dihindari, tetapi justru hukum Taurat itu kudus, benar, baik dan bersifat rohani (Roma 7:12). Hukum Taurat diberikan oleh Tuhan sendiri. Tidak mungkin Tuhan memberikan sesuatu yang bertentangan dengan sifat-Nya sendiri. Justru melalui hukum Taurat manusia mengenal dirinya orang berdosa dan tidak dapat membenarkan dirinya sendiri melalui perbuatan. Hukum Taurat yang dijabarkan dalam Roma 1-8 adalah sarana penghakiman bukan sarana pembenaran.

Kedua, hukum Taurat masih relevan di masa anugerah ini. Tuhan Yesus menggenapkan hukum Taurat bagi orang percaya, sehingga orang percaya sanggup melakukan Taurat dengan kekuatan Roh Kudus. Dan yang perlu diingat bahwa Tuhan telah menaruh hukum-Nya tidak lagi di loh-loh batu yang mati, tetapi di batin 
umat-Nya. Paulus menasehatkan jemaat untuk menerapkan apa yang dituliskan di hukum Taurat, seperti menghormati orang tua. Namun dia juga mendorong umat Tuhan melakukan hukum yang lebih tinggi dari hukum Taurat, yaitu hukum Tuhan atau yang juga disebut sebagai hukum kasih. Bila seseorang mengasihi Tuhan dan sesama maka pasti dia akan menggenapi tuntutan Taurat.

Ketiga, hukum Taurat mempunyai peran dan fungsi yang unik di masa anugerah. Hukum Taurat masih merupakan kehendak Allah bagi orang percaya karena ini masih tetap merupakan pernyataan diri Allah. Paulus sering mengutip Perjanjian Lama untuk meyakinkan dan / atau membesarkan hati orang percaya. Dari hukum Taurat orang percaya mendapat informasi kebenaran dari Perjanjian Lama (Rom 4:23-24). Hukum Taurat juga berfungsi dalam Perjanjian Baru untuk menunjukkan dosa, memandu umat tebusan dalam masyarakat, dan sebagai sumber informasi bagi keputusan-keputusan etika Kristen. Mengabaikan hukum Taurat atau Perjanjian Lama akan kehilangan banyak berkat dari dalamnya.

\section{DAFTAR PUSTAKA}

[1] Alkitab. Jakarta: Lembaga Alkitab Indonesia, 2001.

[2] Gramatika dan Sintaksis, diktat kuliah program pascasarjana, STTII, Yogyakarta, t.t. Matthew Henry's Commentary Vol. 6 Acts to Revelation, Hendricksen Publishers Inc, April, 2006 Tafsiran Alkitab Masa Kini 3: Matius - Wahyu, Yayasan Komunikasi, Bina Kasih/OMF, Jakarta, 1986.

[5] Archer, Gleason L., Encyclopedia of Bible Difficulties: Hal-hal yang Sulit dalam Alkitab, Penerbit Gandum Mas, Malang, 2004.

[6] Barclay, William. The Daily Bible Study : The Letter of the Romans, The Saint Andrew Press, Edinburgh, Scotland,1983. Edisi Terjemahan oleh BPK Gunung Mulia, Jakarta, 2003.

[7] Barclay, William., Bergant, Dianne dan Karris Robert J., Tafsiran Alkitab Perjanjian Baru, diterj. A.S Hadiwiyata, cet.6, Yogyakarta: Kanisius, 2006. 
[8] Barker, Kenneth., Donald Burdick, John

Stek, Walter Wessel, Ronald Youngblood, The NIV Study Bible, Zondervan Bible Publishers, Grand Rapids, Michigan, 1985.

[9] Berkhof, Louis, Teologi Sistematika, jilid 2, diterj. Yudha Thianto, cet. 2, Jakarta: Lembaga Reformed Injili Indonesia, 1995.

[10] Bornkamm, Gunther., Paul Paulus, Harper \& Row Publisher, New York, 1969.

[11] Brauch, Manfred T., Ucapan Paulus Yang Sulit, Seminari Alkitab Asia Tenggara, Malang, 2001.

[12] Brown, Michael L., Hyper Grace, Kasih Karunia Overdosis: Menyingkap Bahaya Kasih Karunia Modern, Penerbit: Nafiri Gabriel, 2015.

[13] Byrne, Brendan., The Problem of Nomos and the Relationship with Judaism in Romans, Source: The Catholic Biblical Quarterly, 62 no 2 Apr 2000, p 294-309

[14] Chia PS, Juanda J. Penafsiran Amilenialisme \& Teologi Kovenan Dalam Memahami Alkitab. Journal KERUSSO. 2020 Sep 10;5(2):1-23.

[15] Chia PS, Juanda J. Penafsiran Amilenialisme \& Teologi Kovenan Dalam
Memahami Alkitab. Journal KERUSSO. 2020 Sep 10;5(2):1-23.

[16] Cletus Groenen OFM, Pengantar ke dalam Perjanjian Baru, cet. 1, Yogyakarta: Kanisius, 1984.

[17] Douglas, JD.The New Bible Dictionary, Inter-Varsity Press, Leicester LEI 7GP, England,1988. Edisi terjemahan oleh Yayasan Komunikasi Bina Kasih/OMF, Jakarta, 2002.

[18] Drane, John, Memahami Perjanjian Baru, diterj. P.G. Katoppo, cet. 9, Jakarta: BPK Gunung Mulia, 2009.

[19] Drewes, B.F., M.Th., Dr. Wilfrid Haubeck, Dr. Heinrich von Siebenthal, Kunci Bahasa Yunani Perjanjian Baru: Surat Roma hingga Kitab Wahyu, BPK Gunung Mulia, Jakarta, 2006

[20] Dunnett, Walter M. Pengantar Perjanjian Baru, cet. 9, Malang: Gandum Mas, 2005.

[21] Duyverman, M.E., Pembimbing ke dalam Perjanjian baru, cet. 11, Jakarta: BPK Gunung Mulia, 1996.

[22] End, Th. van der., Tafsiran Alkitab Surat Roma, BPK Gunung Mulia, Jakarta, 
Jurnal Teologi \& Pelayanan ( Kerusso )

E-ISSN: 2714-9587

P-ISSN: 2407-554X

2003

[31] Holy Bible King James Version.

Oklahoma: Oral Roberts Evangelistic

[23] Ellis, Paul., Hyper Grace Gospel, Light Association, Inc., Tulsa, 1981.

Publishing, 2015.

[24] Enns, Paul, The Moody Handbook of [32] Holy Bible New International Version. International Bible Society, 1984.

Theologi: Buku Pegangan Teologi Jilid 1, diterj. Rahmiati Tanudjaja, cet. 1, Malang: Departemen Literatur SAAT, 2003. , The Moody Handbook of

Theologi: Buku Pegangan Teologi jilid 2, diterj. Rahmiati Tanudjaja, cet. 1, Malang: Departemen Literatur SAAT, 2003.

[26] Ensiklopedi Umum. Yogyakarta: Kanisius, 1973. Tafsiran Alkitab Masa Kini, Jilid 3 Matius - Wahyu, cet. 16, Jakarta: [27] Erickson, Milard J. Teologi Kristen Volume Tiga. Malang: Gandum Mas, 2004. PAUL: Apostle to The Heart [28] Teologi Kristen Volume 2.

Malang: Gandum Mas, 2003.

[29] Hawthorne, Gerald F., Ralph P. Martin., Dictionary of Paul and His Letters, Inter Varsity Press, Leicester, England, 1993.

[30] Hodge, Charles., Commentary on the Epistle to The Romans, Wm. B. Eerdmans Publishing, Michigan, 1974. 
Jurnal Teologi \& Pelayanan ( Kerusso )

E-ISSN: 2714-9587

P-ISSN: 2407-554X

[39] , Tuhan Tanpa Agama, Light

Jakarta: Gunung Mulia, 1995.

Publishing, 2013.

[40] , Sorga Saat Ini, Light

Publishing, 2013. Teologi Perjanjian Baru 2

(Penerjemah: Jan S. Aritonang). Jakarta: Gunung Mulia, 1995.

[41] Ferguson, Duncan S. Biblical , Teologi Perjanjian Baru 3 Hermeneutics: An Introduction. Atlanta: John Knox Press, 1986.

(Penerjemah: Lisda T. Gamadi dkk). Jakarta: Gunung Mulia, 1993.

[42] Godet, Frederic Louis., Commentary on Romans, Kregel Publications, 1979

[50] Hagelberg, Dave., Tafsiran Roma dari Bahasa Yunani, Yayasan Kalam Hidup, 1996 ,

[43] Goppelt, Leonhard. Theology of The New Testament, Vol. 1. Michigan: William B. Eerdmans Publishing Company, Grand Rapids.

[44] Gosnell, Peter W., Law in Romans: regulation and instruction, Source: Novum testamentum, 51 no 3 2009, p 252-271.

[45] Grassmick, D. John., Prinsip-prinsip dan Praktek Eksegesis Bahasa Yunani, diterj. oleh Petrus Maryono, STTII Yogyakarta, t.t.

[46] Groenen C. OFM., Pengantar ke dalam Perjanjian Baru, cet. 3, Yogyakarta: Kanisius, 1987.

[47] Guthrie, Donald. Teologi Perjanjian Baru 1 (Penerjemah: Lisda T. Gamadi).

[51] Halley, Henry H., Penuntun ke dalam Perjanjian Baru,(Matius - Wahyu), diterj. Liem Hong An dan Liem Khiem Soe, Surabya: YAKIN, tt.

[52] Handbook to the Bible. Yogyakarta: Kalam Hidup, 2004.

[53] Hawthrone, Gerarld F. (editor), Dictionary of Paul and His Letters, Inter Varsity Press, 1993.

[54] Hodge, Charles., Commentary: Epistle to The Romans (Wm. B. Eerdmans Publishing, Michigan, 1974.

[55] Hendricksen, William, New Testament Commentary: Exposition of Paul's Epistle to The Romans, Baker Book House, Grand 
Rapids, t.t.

[56] Hunter, A. M. Memperkenalkan Theologia Perjanjian Baru (Penerjemah: F. E. Drake). Jakarta Pusat: BPK Gunung Mulia.

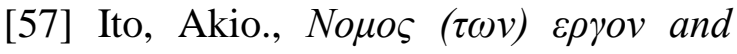

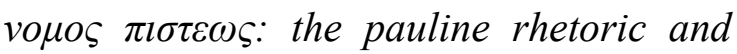
theology of voros, Source: Novum testamentum, 45 no 3 2003, p 237-259. Publication Type: Article

[58] Jacobs, T., Paulus: Hidup, Karya dan Teologinya, Penerbit Kanisius dan BPK Gunung Mulia, tt.

[59] J.I. Packer, dan kawan-kawan, Dunia Perjanjian Baru, diterj. Johan C. Pandelaki, ed. 1, Surabaya - Malang: Yakin dan Gandum Mas, 1993.

[60] Klein, William W. (editors), Introduction to Biblical Interpretation, SAAT Malang, 2012.

[61] Ladd, George Eldon, Teologi Perjanjian Baru Jilid 1, diterj. Dr. Urbanus Selan dan Dr. Henry Lantang, cet. 2, Bandung: Yayasan Kalam Hidup, 2002.

[62] Ladd, George Eldon, Teologi Perjanjian Baru Jilid 2, diterj. Dr. Urbanus
Selan dan Dr. Henry Lantang, cet. 2, Bandung: Yayasan Kalam Hidup, 2002.

[63] Machen, J. Greshan., D.D., The Origin of Paul's Religion, WM. B. Eerdmans Publishing Company, Grand Rapids, Michigan, 1976.

[64] Marantika, Chris., Doktrin Keselamatan dan Kehidupan Rohani, Soteriology dan Spiritual Life. Yogyakarta: Iman Press, 2007.

[65] Kristologi. Yogyakarta: Iman Press, 2008.

[66] Marshall, I. Howard. New Testament Theology Many Witnesses, One Gospel. Illinois: InterVarsity Press, 2004.

[67] Martin, Brice L., Paul on Christ and the law, Source: Journal of the Evangelical Theological Society, 26 no 3 Sep 1983, p 271-282.

[68] McFadden, Kevin W., The fulfillment of the law's dikaiōma: another look at Romans 8:1-4, Source: Journal of the Evangelical Theological Society, 52 no 3 Sep 2009, p 483-497.

[69] M.E. Duyverman, Pembimbing ke dalam Perjanjian Baru, cet. 11, Jakarta: 
Jurnal Teologi \& Pelayanan ( Kerusso )

E-ISSN: 2714-9587

P-ISSN: 2407-554X

BPK Gunung Mulia, 1996.

[77] Packer, J.I., Merril C. Tenney, William

White, Jr. Dunia Perjanjian Baru.

[70] Moulton, Harold K. Leksikon analitis

Surabaya: Yakin, Malang: Gandum Mas,

Bahasa Yunani yang Direvisi (Penerjemah: 1995.

Robert J. Leland, Rev. Stanley Pouw, dan

Pdt. Tandi F. Randa). Yogyakarta: Randa's

Family Press, 2008.

[71] Morrison, Bruce; Woodhouse, John.,

The Coherence of Romans 7:1-8:8, Source:

The Reformed Theological Review, 47 no 1 Jan - Apr 1988, p 8-16.

[72] Murray, John., The Epistle to The Romans, WM. B. Eerdmans Publishing Company, Grand Rapids, Michigan, 1965.

[73] Newman, Barclay M. Jr. Kamus Yunani-Indonesia untuk Perjanjian Baru (Penerjemah: John Miller dan Gerry van Klinken). Jakarta: PT. BPK Gunung Mulia, 2008.

[74] Niftrik, Dr. G.C. Van / Dr. B.J. Boland. Dogmatika Masa Kini. Jakarta: BPK Gunung Mulia, 1981.

[75] O. Cullmann, The New Testament, t.k:tp, 1968.

[76] Oswald, Hilton C., Luther's Works Vol. 25: Lectures On Romans, Concordia 1. Yogyakarta: Penerbit Andi, 1991.

[84] Ryre, Charles C. Teologi Dasar Buku

[79] Pfeiffer, Charles F., Everett F. Harrison (editor), The Wycliffe Bible Commentary Volume 3: Perjanjian Baru, Penerbit Gandum Mas, Malang, 2001.

[80] Poerwadarminta, W.J.S., Kamus Bahasa Indonesia, cet. 12, Jakarta: Balai Pustaka, 1991.

[81] Richards Lawrence, O., Expository Dictionary of bible Words, Grand Rapids, Michigan: Regency Reference Library, 1977.

[82] Ridderbos, Herman. Paulus, Pemikiran Utama Theologinya. Surabaya: Momentum, 2010 .

[83] Rufus, Bob, Living in The Grace of God (United Kingdom: Authentic Media, 2007), 14. Dilihat di Google Books.

Publishing House, Saint Louis, 1972. 

, Teologi Dasar Buku 2.

Yogyakarta: Penerbit Andi, 1992.

[86] Ryrie, Charles Caldwell, Th.D., Ph.D., The Ryrie Study Bible New Testament, Moody Press, Chicago, 1976.

[87] Schnabel, Eckhard J. Rasul Paulus Sang Misionaris, Perjalanan, Strategi, dan Metode Misi Rasul Paulus. Yogyakarta: Andi Offset, 2010.

[88] Snodgrass, Klyne., Spheres of influence: a possible solution to the problem of Paul and the law, Source: Journal for the Study of the New Testament, 32 Feb 1988, p 93-113.

[89] Sukardi, Imanuel., Berkat-berkat Surat Roma, STT Berita Hidup, Surakarta, 2011.

[90] Stott, John R.W., The Message of Romans, Inter-Varsity Press, Leicester, England, 1994.

[91] Sutanto, Hasan. Perjanjian Baru Interlinear Yunani-Indonesia dan Konkordansi Perjanjian Baru (PBIK), Jilid 1. Jakarta: Lembaga Alkitab Indonesia, 2006. Perjanjian Baru Interlinear Yunani-Indonesia dan Konkordansi
Perjanjian Baru (PBIK), Jilid 1. Jakarta: Lembaga Alkitab Indonesia, 2006.

[93] Thiessen, Henry C, Teologi Sistematika, cet. 5, Malang: Gandum Mas, 2005.

[94] Uttley, Bob., Surat Paulus kepada Jemaat di Roma, Bible Lessons International, Marshal, Texas, 2010.

[95] Vine, W.E., Merrill F. Unger, William White, Jr., (editor), Vine's Expository Dictionary of Biblical Words, Thomas Nelson Publishers, New York, 1985.

[96] Whitten, Clark., Pure Grace: The Life Changing Power of Uncontaminated Grace, Shippensburg, PA: Destiny Image, 2012.

[97] Wiersbe, Warren, W., Benar Di Dalam Kristus, diterj. Tinawati Tedjna, cet. 4, Bandung: Kalam Hidup, 1996.

[98] Yancey, Philip., Keajaiban Kasih Karunia, Penerbit Interaksara, 1999.

[99] Zuck, Roy B (editor), A Biblical Theology of The New Testament, (penerjemah: Paulus Adiwijaya) Penerbit Gandum Mas, Malang, 2011. 